The case of Philip Morris

\section{Working to make a disease}

\section{Ruth E Malone}

\section{Philip Morris's "extreme makeover"}

$\mathrm{T}$ hree years ago, I attended a public talk at the University of California, Berkeley School of Business. The topic was corporate social responsibility, and the speaker was David Greenberg, senior vice-president and chief compliance officer at Altria, parent corporation of tobacco giant Philip Morris. Greenberg was a smiling, somewhat self effacing guy about my own age, and he began his talk by saying how he appreciated our willingness to listen, because he wanted to tell us some things about his company that "might surprise" us.

Greenberg said the organisation had recently done a lot of soul searching and realised it needed to change-there was a new "openness" in "Altria's journey," as Greenberg put it, in which the organisation had "outed ourselves." He alluded to "almost religious" battles within the corporation about the "new" stance of "responsibility," as part of which Altria/ Philip Morris finally admits (on its website and in direct mail materials and advertisements) that cigarettes cause disease. The company sounded near-heroic as Greenberg boasted of its "partnering" with leading health organisations in support of US Food and Drug Administration (FDA) regulation of tobacco.

For about a nanosecond, it was almost tempting to believe.

However, several recent studies (including one in this issue of Tobacco Control) $)^{1-4}$ suggest that Greenberg's talk, and remarkably similar ones being given by Philip Morris executives all over the country, were all just part of the gussiedup new face of Philip Morris created by its corporate image makeover campaign, PM21. PM21 was an extension of a long-term plan for convincing the public and policy-makers that the corporation formerly known as Philip Morris had changed. $^{2}$

Yet in litigation related to the diseases its products cause with ordinary use, Philip Morris has not changed, as Friedman clearly shows in her paper in this issue of Tobacco Control. ${ }^{4}$ In the courtroom, Philip Morris lawyers continue to mount the same cognitively dissonant two-pronged defence, arguing that "everyone knows" cigarettes cause disease (and therefore the consumer accepted the risks voluntarily in starting to smoke), and simultaneously that "nobody knows" exactly what the causal links between cigarettes and disease are (and therefore the company cannot be held responsible for anyone's specific disease). Friedman argues convincingly that Philip Morris's new "openness" on its website was undertaken primarily to head off the prospect of severe penalties in the US Department of Justice case, and to soften prospective jurors' inclination to "punish" the company in the penalty phase of other civil trials. The plan has met with some success. As Szczypka and colleagues reported, by late 2003, the media having been saturated with Philip Morris image-makeover messages, some $58 \%$ of the public thought that the tobacco industry was somewhat or much more "responsible" than in the past ${ }^{3}$ — even as they still distrusted the industry as a whole.

To be responsible would mean "making a difference" by ceasing to aggressively promote products that cause addiction and kill consumers

So what does it really mean to admit on a website that cigarettes cause disease, while maintaining in the courtroom that they do not? Does it mean, as the corporation claims, that it has become a "responsible marketer of a risky product?" Or does it mean that the company has socially engineered a fine new deception by raising doubt not about the nature of its products but rather about the nature of its own intentions? The best available evidence suggests the latter.

To be responsible would mean accepting responsibility for past fraudulent conduct. Altria/Philip Morris, however, has not been willing to do that, despite having been a leader of worldwide, decades-long efforts to deceive the public. ${ }^{56}$

To be responsible would mean "making a difference" by-at minimum-ceasing to aggressively promote products that cause addiction and kill consumers under normal use conditions. For most consumer products companies, responsibility means pulling a product from the market under such circumstances. But such a move would mean admitting something that the industry still does not quite want to admit-that its products really are that deadly-as well as putting an end to its profits.

To be responsible might even involve an apology for engineering the products that caused the addiction, suffering and deaths of millions of customers. But to this day, Altria/Philip Morris characterises consumer addiction to its products as "choice," even castigating tobacco disease victims in court as having made "unfortunate" choices. ${ }^{7}$ The choices Altria/Philip Morris made in working actively to hook them are ignored.

As my colleague Elizabeth Smith (who also attended the Greenberg meeting) noted at the time, Greenberg admitted that cigarettes caused disease (though he stopped short of death). He emphasised, however, that Philip Morris would not stop selling them unless they were outlawed, because other companies would continue to sell them. He said that Philip Morris would not unilaterally adopt the measures that then-proposed FDA regulations would have required (regulations Philip Morris claimed it supported) because that would create an unlevel playing field and threaten to reduce the company's market share. But, as my colleague observed, true responsibility means doing the right thing even if it is not required by law, even if other people do not join you, and even if it costs you. Clearly, that's not the kind of "responsibility" Philip Morris is ready to accept. Even "extreme makeovers," it seems, only go so far.

\section{ACKNOWLEDGEMENTS}

The author wishes to thank Elizabeth (Libby) Smith for her helpful comments on earlier drafts of this manuscript.

Tobacco Control 2007; 16:361-362

doi: 10.1136/tc.2007.023952

Correspondence to: Ruth E Malone, RN, PhD Professor and Vice Chair, Department of Social \& Behavioral Sciences, University of California, San Francisco, 3333 California Street, Suite 455, San Francisco, CA 94118, USA; ruth.malone@ucsf. edu

Competing interests: The author owns one share of Altria/Philip Morris stock for research and advocacy purposes and served as an industry documents consultant in United States of America v. Philip Morris et al.

\section{REFERENCES}

1 McDaniel PA, Malone RE. Understanding Philip Morris's pursuit of US government regulation of tobacco. Tob Control 2005; 14:193-200.

2 McDaniel PA, Smith EA, Malone RE. Philip Morris's Project Sunrise: weakening tobacco 
control by working with it. Tob Control 2006;15:215-23.

3 Szczypka G, Wakefield MA, Emery S, et al. Working to make an image: an analysis of three Philip Morris corporate image media campaigns. Tob Control 2007; 16:344-50.

4 Friedman L. Philip Morris's website and

television commercials use new language to mislead the public into believing it has changed its stance on smoking and disease. Tob Control 2007;17:e9

5 Francey N, Chapman S. "Operation Berkshire": the international tobacco companies' conspiracy. BMJ 2000;321:371-4

6 United States of America v Philip Morris, et al. Amended final opinion, Civil Action No 99-2496
(GK), United States District Court for the District of Columbia, 2006. Available: http://

www.usdoj.gov/civil/cases/tobacco2/

amended\%20opinion.pdt.

7 Balbach ED Smith EA Malone RE. How the health belief model helps the tobacco industry: individuals, choice, and "information." Tob Control 2006;15(Suppl 4):iv37-iv43.

\section{The Lighter Side}
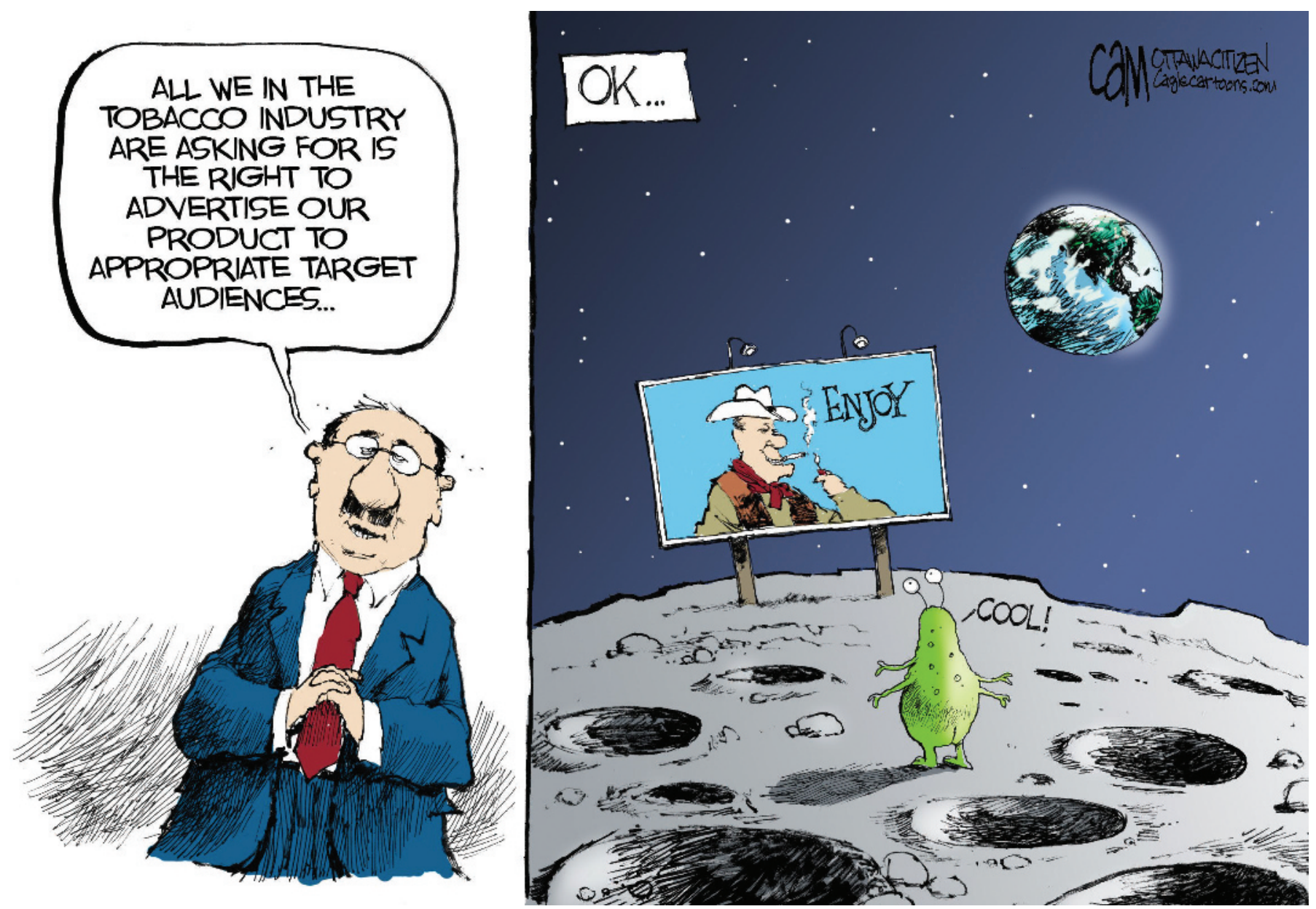

(๑) Cardow, Ottawa Citizen. 